highest percentage (39.9 per cent) of the 102,830 victims of road traffic accidents who needed hospital treatment. Fractures of different parts of the body made up most of the rest of the total; burns, however, accounted for only $0 \cdot 1$ per cent of road traffic injuries. Poisons caused a high proportion of accidents in the home 33.1 per cent out of the estimated total of 133,490 home accidents noted in the enquiry. Figures are given for all kinds of poisons-even strychnine and belladonna are included in the results.

\section{Agreement Signed}

A TEOHNOLOGICAL agreement between the United Kingdom and the USSR which has been talked of for some time was signed last week by the technology chiefs of the two countries (see Nature, 216, 1060; 1967). The Russian delegation, which spent four days in London completing negotiations with the Ministry of Technology, was led by Academician V. A. Kirillin, Deputy Chairman of the Council of Ministers and Chairman of the State Committee of the Council of Ministers of the USSR for Science and Technology. Mr Anthony Wedgwood Benn, the minister, and Mr Fred Mulley, Minister of State at the Foreign Office, signed on behalf of the British Government. The agreement provides for investigation of topics of mutual interest to the two countries at all levels, and is seen as the beginning of a "special industrial relationship". Mr Wedgwood Benn hopes that each side will "discover what is interesting, and pursue it".

The ministers, or their deputies, will meet once w year to review the working of the agreement, with reference to the progress of scientific, technologicel and economic co-operation. Joint working parties will determine the fields for cooperation and will recommend specific subjects for investigation in the fields of research, development, technology and organization of industry. Contacts at all levels will be encouraged as a means of turning the agreement into action. Exchange visits for studies, training and consultation will be arranged. Facilitics will be provided for research and practical experience in each country and scientific and technical information will be exchanged. It is expected that licensing arrangements will be made to suit circumstances as they arise. The agreement places no limit on the joint work that can be done, as it provides for "any form of co-operation in applied science and technology as may be mutually agreed".

Five subjects which have been agreed, and are to be investigated by working groups, are educational technology, transport technology, materials research, information storage, processing and retrieval and non-conventional methods of food production. The ten items under the heading of industrial technology include the topics already being investigated by the Confederation of British Industry following the visit of a delegation to Russia last autumn.

\section{Viking Ships on the Move}

\section{from Angela Croome}

Srx years ago the Danish National Museum recovered the timbers of five 1,000-year-old Viking ships from Roskilde Fjord in an intensive and precisely calculated 3-month exercise which followed several years of underwater investigation. The ships, dated by carbon14 measurements of caulking material, were known to be expendable hulks stripped down to essentials and sunk with stones across the main navigation channel to block access to the rich settlement at the head of the fjord which later became the medieval Danish capital of Roskilde. The fjord was shallow, so that a low cofferdam was enough to enable pumping out and salvage of the timbers (see picture).

By now the first ship has completed the long and tricky "pickling" process needed to preserve its fragile timbers in air, and the work of turning these back into a ship can begin. This will take place in a specially built ship museum on the banks of the Roskilde Fjord where the first ship to complete processing is to move this week. Museum staff expect reassembly of the first ship to be completed this year when the new museum will be: opening to the public. After that, visitors can watch the other ships assembled one by one. The ship being moved to the museum this week is made up of 5,000 individual pieces of wood. These have taken from 6 months to 2 ycars to be "rehabilitated"- the waterfilled gaps must be filled with ethyl-glycol so that the wood, saturated for a thousand years in water, will not shrink when exposed to air. A cycling process in solution tanks heated to $60^{\circ} \mathrm{C}$ has been employed and has taken longer than originally expected. It may yet be: a vear or so before the remaining ships are ready for

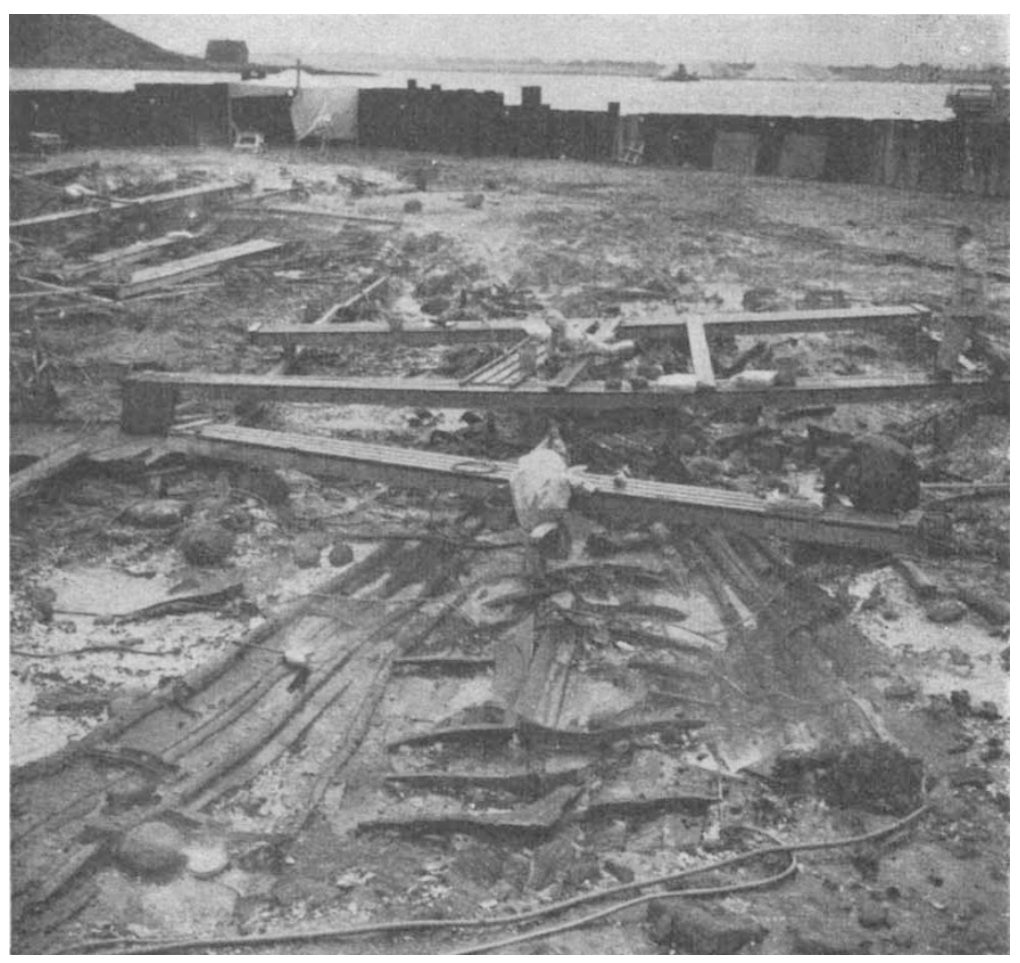

The skeleton of one of the five tenth-century Viking ships emerges from the mud of Roskilde Fjord. When this picture was taken, in August 1962, the work of clearing the ships of mud and stones was two-thirds complete. Garden sprinklers are in use to keep the exposed wood damp. 